\title{
AN UNUSUAL ICE FORMATION ON THE OTTAWA RIVER
}

\author{
By L. W. Gold and G. P. Williams \\ (Snow and Ice Section, Division of Building Research, National Research Council, \\ Ottawa, Canada)
}

\begin{abstract}
Aestract. An unusual humped formation of floating ice, about $10 \mathrm{~m}$. high, roo m. wide and $\mathrm{I}, 200 \mathrm{~m}$. long, was observed on the Ottawa River, Canada. Some characteristics of this formation are described. The cause of the humps was found to be frazil ice deposited in a trench about $90 \mathrm{~m}$. wide, $90 \mathrm{~m}$. deep and $1,200 \mathrm{~m}$. long. The frazil ice was formed in rapids up-stream from the humps.
\end{abstract}

RÉsumé. Une formation bombée inhabituelle de glace flottante d'environ ro mètres de haut, Ioo mètres de large et 1200 mètres de long a été observée sur la rivière Ottawa, Canada. On décrit quelques caractéristiques de cette formation. On attribue les bombements à du sorbet (mélange laiteux de glace et d'eau) déposé dans une fosse, d'environ 90 mètres de large, go mètres de profondeur et I 200 mètres de long. Le sorbet a été formé dans des rapides en amont des bombements.

Zusammenfassung. Eine in ungewöhnlicher Weise bucklige Bildung schwimmenden Eises ro m dick, $100 \mathrm{~m}$ breit und $1200 \mathrm{~m}$ lang, wurde im Ottawa Fluss, Canada, beobachtet. Einige charakteristische Eigenheiten dieser Bildung werden beschrieben. Die Ursache der Buckel wurde darin gefunden, dass es sich um Wassereis handelt, das in einem etwa $90 \mathrm{~m}$ breiten, $90 \mathrm{~m}$ tiefen und $1200 \mathrm{~m}$ langen Graben abgelagert worden ist. Das Wassereis bildete sich in Wasserfällen stromaufwärts von den Buckeln.

In February 1962, the formation of unusually large humps in the ice cover of the Ottawa River was brought to the attention of the Snow and Ice Section of the Division of Building Research, National Research Council. The humps developed about $6 \mathrm{~km}$. below the town of Hawkesbury at a site about half-way between Montreal and Ottawa.

The disturbed area of the ice cover was about $\mathrm{I}, 200 \mathrm{~m}$. in length and at a site where the river narrowed from about $55^{\circ} \mathrm{m}$. to a little under $300 \mathrm{~m}$. Within this area were two very large humps between $45^{\circ}$ and $600 \mathrm{~m}$. long and about $\mathrm{I} 5 \mathrm{O}$. wide (Fig. I). In the photograph, the river flows from the top to the bottom. Figure i shows to a limited extent the widening of the river above and below the site of the humps.

Each hump rose gradually to a height between 10 and $12 \mathrm{~m}$. above the water surface. This can be seen in Figure 2 where part of the down-stream hump is shown in profile. The up-stream hump can be seen in the background.

At the top of the humps were several large longitudinal cracks (Fig. I), up to a metre in width. Although the cracks were usually snow-filled, at some places the upper part of the humps was exposed in profile as shown in Figure 3. It could then be seen that the surface of the humps consisted of a layer of clear river ice some $25 \mathrm{~cm}$. thick overlain with snow. Beneath the clear ice was a porous ice deposit which had a density of about one-third that of normal ice.

The cause of the formation of the humps presented an interesting problem to unravel. Up-stream from the humps, extending for a distance of almost $6 \mathrm{~km}$., is a turbulent section of river known as the Long Sault Rapids. In this section the water flow is so rapid that during winter no ice cover develops but rather the ice formed is carried in suspension as an agglomerate of needles and plates known in Canada as frazil ice. It would appear that this frazil ice is carried down-stream and deposited at the under-surface of the ice cover. This would require that the river slow down considerably in the narrow section where the humps are located, indicating that the water must be quite deep. That an ice cover some $25 \mathrm{~cm}$. thick formed at this site is further evidence that the water speed must be low, because it is known that ice covers will not form readily on water flowing at speeds in excess of about $0.5 \mathrm{~m}$. $/ \mathrm{sec}$.

Two trips were made to the site of the humps during the winter of $1_{9} 6_{1}-62$. At the time of the first visit, there was an almost vertical rock face about $9 \mathrm{~m}$. high on the north side of the river at the shore edge. The upper part of the face can be seen in Figure 3 . The top of the humps was about level with the top of the rock face. At the time of the second visit the water level had risen about $9 \mathrm{~m}$. due partly to spring run-off and partly to the closing of a new dam 
down-stream. Only about $0.5 \mathrm{~m}$. of the top of the rock face was above water. The ice humps had risen as well showing that they were floating. The shape of the humps could now be seen clearly against the background of trees on the opposite side of the river. The space between the shore and the hump edge was filled with ice pans and water was visible at some locations. This, as well as the edge of the rock face, can be seen in Figure 2.

Since the ice humps float, the amount of ice beneath the surface must be about nine times that above. This indicates that the maximum depth of the water must be at least $90 \mathrm{~m}$. Hydrographic maps of the river showed only that the depth was greater than $18 \mathrm{~m}$. This was the maximum depth recorded by parties surveying the river for hydrological and navigational purposes.

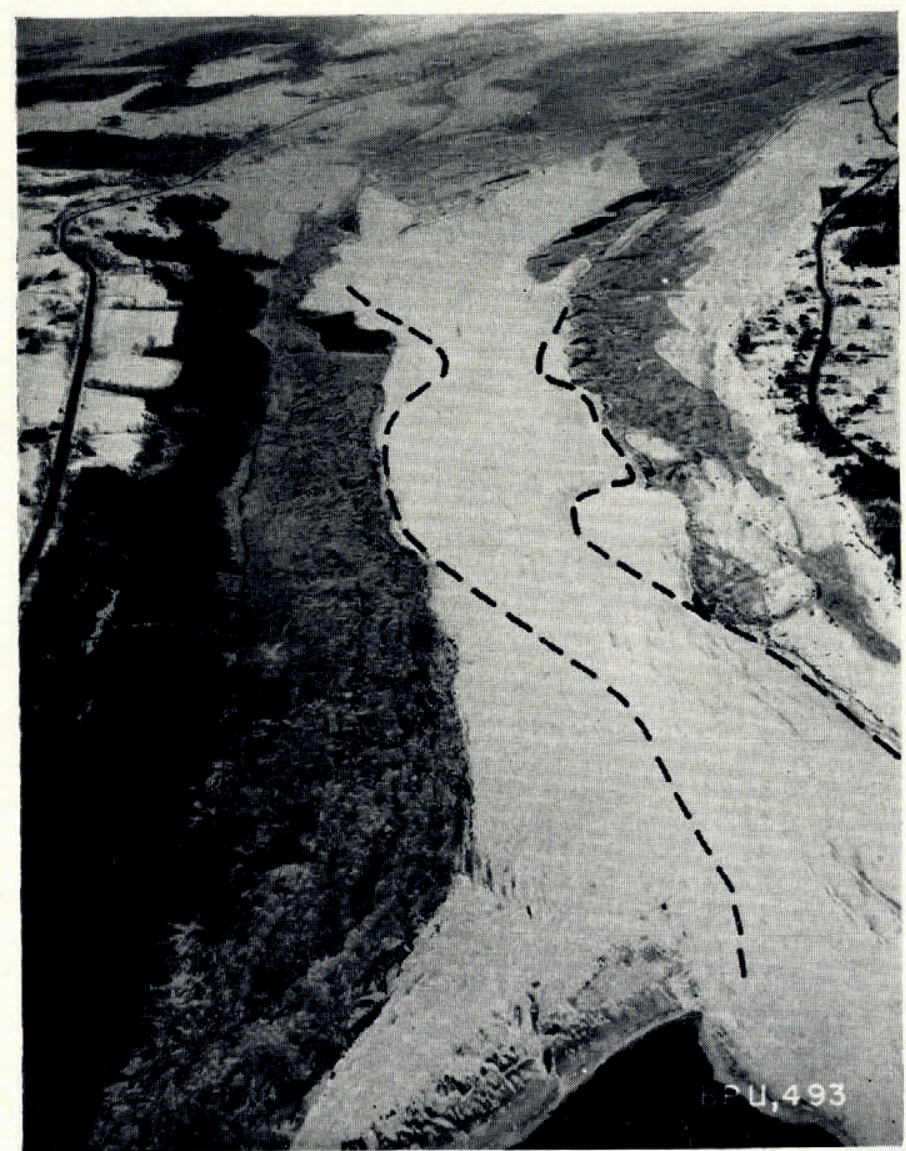

Fig. 1. Aerial view of ice humps at Greece's Point taken from an altitude of about $600 \mathrm{~m}$. Greece's Point and the highway are seen on the right. The dashed lines outline the humped region

After the ice had melted in the spring, arrangements were made to measure the water depth. Unfortunately, the echo-sounding equipment available had a range of only i $50 \mathrm{ft}$. $(45 \mathrm{~m}$.). The observations with the echo sounder were supplemented therefore by measurements made with a sounding line.

Three cross-sections were obtained with the echo sounder, one near each end of the site and one at the centre. A run was made as well in the longitudinal direction. Figure 4 shows 


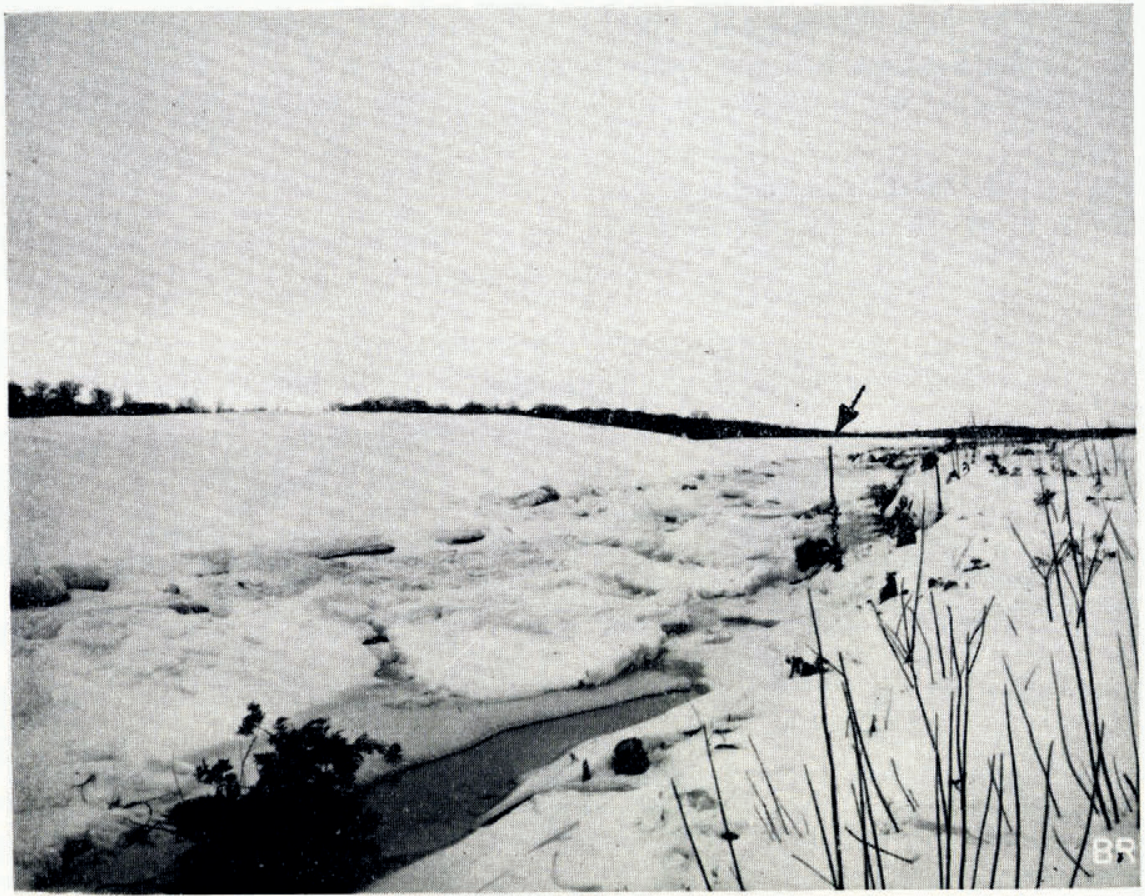

Fig. 2. The ice humps photographed from the north shore of the Oltawa River. Ice pans and water can be seen between the rock face at the shore and the edge of the ice humps. The arrow locates the up-stream hump

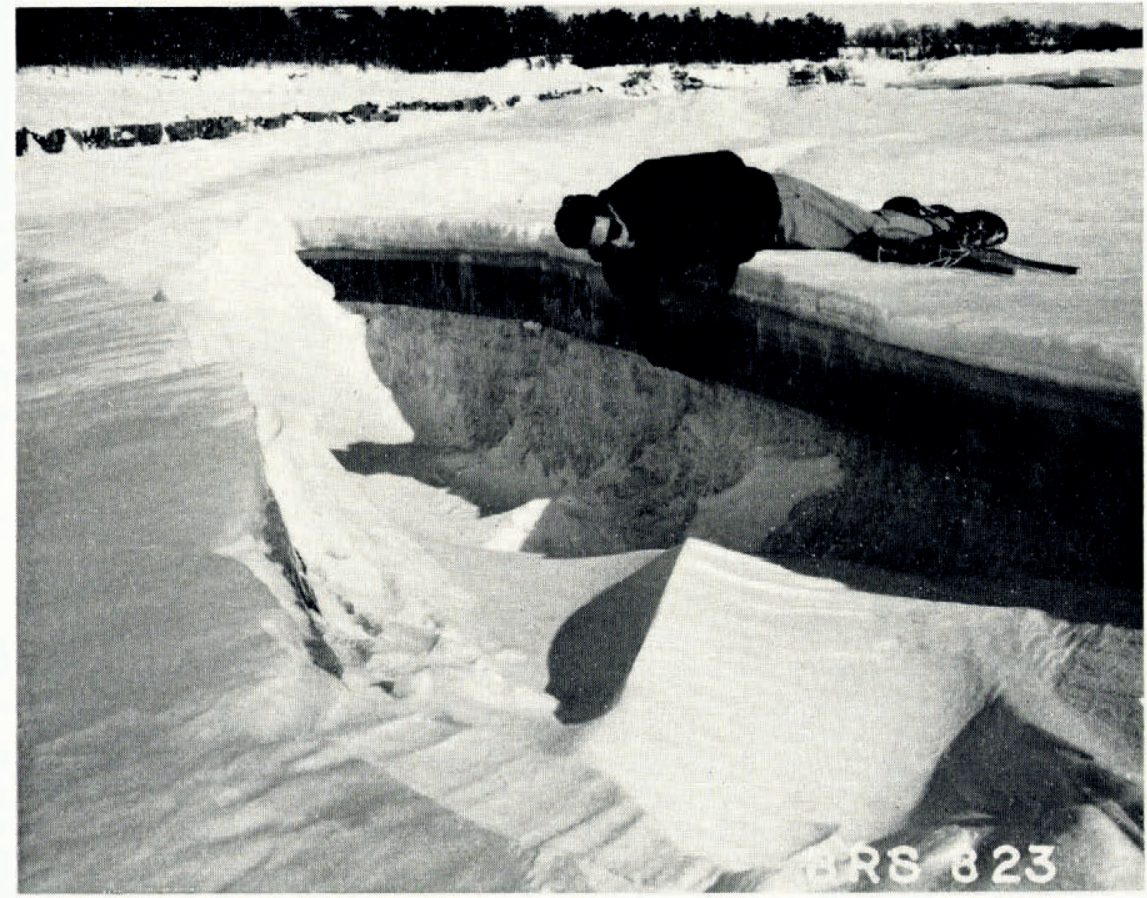

Fig. 3. An exposure of the upper part of one of the humps by a longitudinal crack. Note the $25 \mathrm{~cm}$. of clear river ice underlain by porous ice 
the approximate location of the $45 \mathrm{~m}$. contour line and the cross-section at location AA. Two soundings with the line near location AA gave depths of $79 \cdot 5$ and $9 \mathrm{I} \cdot 5 \mathrm{~m}$. These observations showed that there is a trench about $\mathrm{I}, 200 \mathrm{~m}$. long, $90 \mathrm{~m}$. wide with walls about $75 \mathrm{~m}$. high at
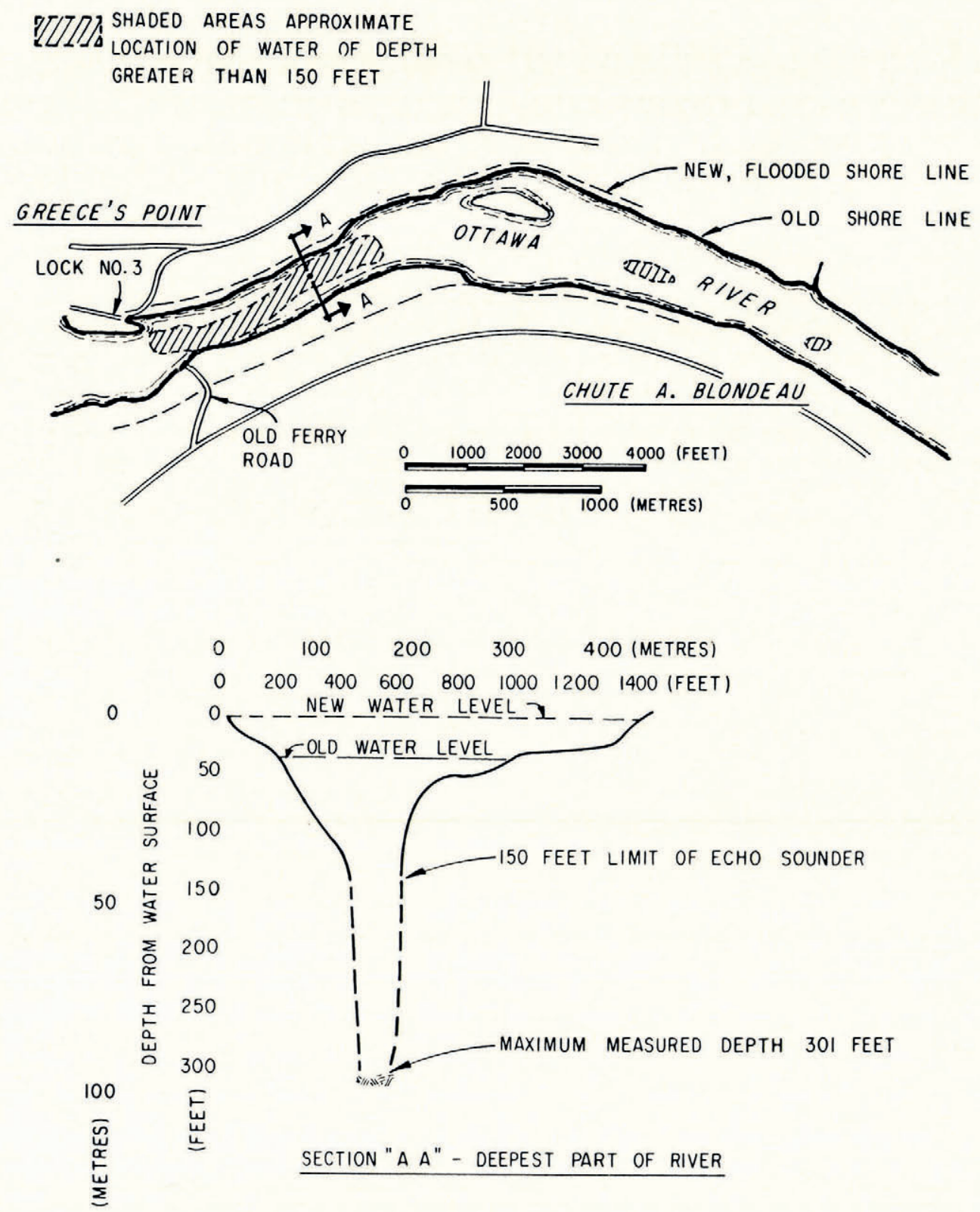

Fig. 4. Map and cross-section of ice hump location

the site where the ice humps formed. They show also that the rock face observed on the north shore of the river on the first visit was the edge of the trench. 
A trench of this size was indeed an interesting discovery and of considerable geological significance. Consultation of geological maps showed that it is located in a limestone and dolomite formation of early Ordovician age. Back from the river a short distance, the limestone is overlaid with a shale formation. There is a fault running in a north-easterly direction on the south side of the river that intersects the river at the up-stream end of the trench. Pot-holes are present in the rocks some $6 \mathrm{~m}$. above the present water level, indicating a much higher water level and very rapid flow at some earlier date. The bottom of the trench is about $45 \mathrm{~m}$. below the present sea-level. Although the speed of the river is reduced considerably at this site, the trench has not filled by sedimentation.

The observations showed that the humps are formed by the deposition of frazil ice in the more slowly moving water in the trench. The frazil ice is manufactured up-stream in the rapids. The size of the humps and the trench is a dramatic illustration of the great quantities of ice that can be produced in fast flowing water in even the more temperate regions of Canada, and an indication of the difficulties that can plague hydro-electric installations exposed to such conditions.

The humps are a familiar and recurring feature of this section of the river. An early explorer, Chevalier de Troyes, noted their presence in his "Journal of an expedition to Hudson Bay" in I686 (Troyes, I918). Unfortunately, the humps will probably never form again, at least within the period of industrialized man, because in the fall of I96 I the Carillon Dam was completed. This dam, located about $9 \mathrm{~km}$. down-stream from the site, was closed in the spring of 1962 . The increase in the water depth observed on the second visit to the site was a consequence of this. When the water depths were measured, the water level was about I0. $5 \mathrm{~m}$. above the previous normal. The depths at the two sites sounded were therefore about $69 \cdot 5$ and $8 \mathrm{I} \cdot 5 \mathrm{~m}$. when the humps formed.

In the future, the control level of the river at the site of the humps will be about $12 \mathrm{~m}$. above the previous normal. The water level at the Long Sault Rapids will probably be raised to the extent that the velocity of the water will be reduced sufficiently to allow an ice cover to form. This will remove the source of frazil ice.

It is unfortunate that just at the time when attention was drawn to this unique natural phenomenon, it should fall victim to progress before an adequate record of its features could be obtained.

\section{Acknowledgements}

The authors are greatly indebted to Miss H. Lambart, Greece's Point, for informing them of the ice hump and for being their guide during visits to the site. They also wish to express their appreciation to the Photographic Section of the Division of Mechanical Engineering, National Research Council, for the air photographs, and to the Hydraulics Section of the same Division for its assistance in measuring the water depth.

This paper is a contribution of the Division of Building Research, National Research Council, and is published with the approval of the Director of the Division.

MS. received 12 October 1962

\section{REFERENCE}

Troyes, Chevalier P. de. 1918. Fournal de l'expédition du Chevalier de Troyes à la Baie d'Hudson, en I636, édité et annoté par l'Abbé Ivanhoe Caron. Beauceville, La Compagnie de l'Éclaireur. 